\title{
Vigor of zinnia seedlings produced in alternative substrate in trays with different cell size
}

\author{
Rogério Gomes Pêgo*, Luiz Fernando de Sousa Antunes, Aline Roberta Caetano Silva
}

\begin{abstract}
The zinnia (Zinnia elegans Jacq.) is an ornamental plant used in landscape composition and presents great potential for cultivation as a cut flower, potted. Faced with the new trend of integrated flower production, that proposes more environmentally friendly practices aiming at sustainability, there is a need to determine alternative substrates that allow the production of quality seedlings. Therefore, this study aimed to evaluate the vigor and quality of zinnia seedlings produced in alternative substrates in trays with different cell size. Two different types of trays of expanded polystyrene with different cell size were tested as following: 128-cell and 200-cell trays with a volume of $40 \mathrm{~cm}^{3}$ and $16 \mathrm{~cm}^{3}$, respectively. For the growth of the seedlings, three types of substrate were tested: commercial substrate; composting of organic waste; mixture of sand, soil and carbonized rice husk in the proportion of 1:1:1 (v:v:v). The experiment was a completely randomized design, using 24 trays in a factorial arrangement $3 \times 2$ (substrate $\mathrm{x}$ tray cell size), with four replicate and eight seedling per replicate. The phytotechnical characteristics evaluated were plant height, number of leaves, root length and dry weight of plants, the vigor of seedlings and clod stability was determined by rating scales. The physicochemical and physical proprieties of organic substrate enables produce high quality seedling using 128-cell trays, but the 200-cell trays also produce good quality seedling, having the advantage of using smaller volumes of substrates.
\end{abstract}

Keywords: Zinnia elegans, attractive plants, floriculture, gardening, agroecology.

\section{Resumo}

Vigor de mudas zinnia produzidas em substratos alternativos em bandejas com diferentes volumes de células A zínia (Zinnia elegans Jacq.) é uma planta ornamental utilizada na composição da paisagem e apresenta grande potencial para o cultivo como flor de corte, plantas envasadas ou plantas atrativas com grande potencial para aumentar a diversidade de insetos em sistemas agroecológicos de cultivo. Diante da nova tendência de produção integrada de flores, que propõe práticas ambientalmente corretas visando a sustentabilidade do sistema produtivo é necessário determinar substratos alternativos que permitam a produção de mudas de qualidade. Este trabalho teve como objetivo avaliar o vigor e a qualidade de mudas de zínia produzidas em substratos alternativos em bandejas de diferentes tamanhos de células. Dois tipos diferentes de bandejas de poliestireno expandido foram testados como se segue: bandeja de 128 células e 200 células com um volume de $40 \mathrm{~cm}^{3}$ e $16 \mathrm{~cm}^{3}$ por célula, respectivamente. Para o crescimento das mudas, foram testados três tipos de substrato: substrato comercial; compostagem de resíduos orgânicos na proporção de 1:1:1 (v:v:v). O delineamento experimental foi inteiramente casualizado, em arranjo fatorial 3x2 (substrato x tamanho de bandeja celular), com quatro repetições e oito plântulas por repetição. As características fitotecnicas avaliadas foram altura de plantas, número de folhas, comprimento de raízes e peso seco de platntas; vigor das mudas e a estabilidade do torrão foram determinados através de escalas de notas. As propriedades físicas e fisicoquímicas do substrato orgânico possibilita a produção de plantas de qualidade em bandejas de 128 células, no entanto as bandejas de 200 células também produz mudas de qualidade, tendo como vantagem o uso de menores volumes de substratos.

Palavras-chave: Zinnia elegans, planta atrativa, floricultura, jardinocultura, agroecologia 


\section{Introduction}

The zinnia (Zinnia elegans Jacq.) is a species of the Asteraceae family used in landscape composition and presents great potential for cultivation as cut flower or potted plants (Iqbal et al., 2012; Ahmad et al., 2015). Many studies have been carried out to understand the multiplicity of uses of these plants such as ornamental propose, medicinal or as attractive plants with great potential for increasing the diversity of insects in agroecological farming systems (Wijesinghe et al., 2017, Gomaa et al., 2019).

Zinnia plants have been cultivated in Integrated Agroecological Production Systems, known as "Fazendinha Agroecológica" located Seropédica- RJ, with the objective of attracting pollinating insects or natural enemies to increase ecological diversity in organic agricultural systems. Additionally, it is known that zinnia flowers are visited by a wide variety of insects such as Apis cerana, Apis mellifera, Eristalomyia tenax, Osmia cornifrons, Polistes chinensis, Parnara guttata and Lucaena phlaeas daimio (Miyajima et al., 1995).

The production of zinnia seedlings for agroecological system, whether for the landscape composition, as a cut flower or for the attractive plants, must obey the rules for Brazilian agroecological production, and the use of organic substrates (Brasil, 2011). Many substrates can be used for this purpose, however, it is recommended to prioritize those substrates that are easily accessible and low cost; that present the suitable physical and chemical proprieties and allow obtain high-quality plants (Barbosa and Lopes, 2007). Therefore, it is possible to mention some components frequently used to produce seedlings of ornamental species, for example, substrates coming from composting of different organic wastes, sugarcane bagasse, carbonized rice husk, pinus husk and coconut fiber, as well as the mixing of these materials with soil or sand (Riaz et al., 2008; Ali , 2011 Santos Júnior et al., 2014; Silva et al., 2018). The great advantage of using these residues can be highlighted as the formulation of an alternative mix of substrates implying on lower production costs, reducing the environmental impact erstwhile produced by the discard of these materials (Sousa et al., 2011).

The physicochemical proprieties of substrates directly affect the root growth and vigor of growing plants, such as $\mathrm{pH}$, electrical conductivity, density and porosity. More specifically in the production of agroecological seedlings, the substrate has contain nutrients that enable the initial development and production of high vigor plants. (Leal et al., 2007; Sardoei et al., 2014; Moraes et al., 2016). To the regulation the physicochemical proprieties was recently established standards by to commercialization of commercial organic substrate, a breakthrough for agroecological production system in Brazil (Brasil, 2011). specifically for zinnia production this is important because previous studies confirm that the selection of appropriate substrate of zinnia potted flowering was very important from an aesthetic and marketing point of view (Sardoei et al., 2014).

The volume of substrates used to cultivate can also determine the quality of seedlings. In ornamental horti- culture, there is a tendency of using trays with small cells, since a greater number of seedlings that can be grown per area of greenhouses; in the same way, it will be spent smaller amounts of substrate for the production of seedlings and, consequently, the lower production cost (Godoy and Cardoso, 2005). It is known that potted zinnia plants respond differently to the size of pot used for cultivation; plants grown in containers with smaller volumes substrate to have lower height lengths without significant effects on ornamental quality (Pinto et al., 2003).

Due to the information demand that allows the production of zinnia seedlings in alternative substrates with potential for the insertion of this species in agroecological production systems, this work aiming was to evaluate the vigor and quality of zinnia seedlings produced in alternative substrates in different cell volumes.

\section{Material and Methods}

The zinnia seeds cultivar 'Gigante da California Rosa' used in this work was obtained from commercial companies. The seeds were sown in the month of February to a depth of $1,0 \mathrm{~cm}$ depth. Two different types of trays with different cell size were tested as following: 128-cell expanded polystyrene trays with a volume of $40 \mathrm{~cm}^{3}$ per cell; and 200-cell expanded polystyrene trays with a volume of $16 \mathrm{~cm}^{3}$ per cell. For the growth of the seedlings three types of substrate were tested: commercial substrate; organic substrate (obtained by composting of agricultural wastes); mixture of sand, soil and carbonized rice husk in the proportion of 1:1:1 (v:v:v). The experiment was perfomed usinf 24 trays in a completely randomized design, in a factorial arrangement $3 \times 2$ (substrate $x$ tray cell size), with four replicate and eight seedling per replicate.

The physicochemical analyzes of the substrates $(\mathrm{pH}$ and electrical conductivity) were performed in distilled water solution $(5: 1 \mathrm{v} / \mathrm{v})$, according to the method described by Brasil (2008). Regarding physical characteristics, the percentages of total porosity, macroporosity and microporosity, water retention capacity and volumetric density were determined using the adapted methodology of Teixeira et al. (2017) and Brasil (2008). Two seeds per cell were sown, and 10 days after sowing, they were thinned to one seedling per cell. Zinnia seedlings were grown in a greenhouse with a $50 \%$ shade mesh at $1.80 \mathrm{~m}$ height, with intermittent periods of spraying every 15 seconds with an interval of $60 \mathrm{~min}$. The average temperature in the nursery during the experimental period was approximately $28^{\circ} \mathrm{C}$.

Zinnia seedlings were evaluated at 21 days after sowing. Seedlings in all treatments were removed from the containers with clod to analyses of the vigor of seedling and stability of clod. The vigor of the seedlings (VS) was evaluated by the attribution of notes, according to the following scale: note 1: poor vigor, nutritional deficiency, poorly developed plants, reduced number of leaves, note 2 : regular vigor, notorious yellowing, 4 to 5 leaves, size up to $5 \mathrm{~cm}$, but with nutritional deficiency well highlighted; note 3: good vigor, 4 to 5 leaves, height greater than $5 \mathrm{~cm}$ with yellowish prominent; note 4: great vigor, above of 5 leaves, 
height greater than $5 \mathrm{~cm}$; according to the methodology proposed by Franzin et al. (2005) and adapted by Antunes et al. (2018).

The clod Stability (CT) was evaluated by the attribution of notes, as follows: note 1: low stability, $50 \%$ or more of the clod is retained in the vessel at removal of the clod and the clod does not remain cohesive; note 2 : between $30 \%$ and $50 \%$ of the clod is retained in the container when the molt is removed, but the clod does not remain cohesive; note 3: regular, between $15 \%$ and $30 \%$ of the clod is retained in the container when removing the seedling, but does not remain cohesive; note 4: good stability, the clod is detached completely from the container with up to $90 \%$ cohesion and maximum loss of up to $10 \%$ of the substrate; note 5 : great stability, the clod is detached completely from the container and more than $90 \%$ of it remains cohesive, with losses of less than $10 \%$ of the substrate; according to adaptation of scale propose by Antunes et al. (2018).
The number of leaves was also counted and the height of seedlings and length of roots of the seedlings were measured with a millimeter rule. After measuring the seedlings was packaged in kraft paper bags and dried in an oven with forced air circulation at $65^{\circ} \mathrm{C}$, to obtain the dry weight of seedlings.

The data were tabulated and subjected to descriptive statistics and analysis of variance by the F-Test and the groups were compared using the Tukey test, using the $5 \%$ level of significance using the software Rbio (Bhering, 2017).

\section{Results and Discussion}

Characterization of physicochemical and physical properties of the substrates used in the production of the Zinnia seedlings, presented in Table 1, reveal the occurrence of statistical differences between the substrates for all evaluated parameters.

Table 1. Chemical and physical properties of the substrates used in the production of the Zinnia seedlings

\begin{tabular}{|c|c|c|c|}
\hline \multicolumn{1}{|c|}{ Parameters } & \multicolumn{3}{|c|}{ Substrates } \\
\hline Physical-chemical characteristics & Comercial substrate & Organic compound & Mix substrate \\
\hline $\mathrm{pH}$ & $6.36 \mathrm{~b}$ & $8.35 \mathrm{a}$ & $5.79 \mathrm{c}$ \\
\hline Electric conductivity $\left(\mathrm{dS} \mathrm{m}^{-1}\right)$ & $0.74 \mathrm{a}$ & $0.26 \mathrm{~b}$ & $0.07 \mathrm{c}$ \\
\hline Physical characteristics & Comercial substrate & Organic compound & Mix substrate \\
\hline Macroporosity $(\%)$ & $40.71 \mathrm{a}$ & $36.66 \mathrm{~b}$ & $38.01 \mathrm{ab}$ \\
\hline Microporosity $(\%)$ & $47.87 \mathrm{a}$ & $46.51 \mathrm{a}$ & $24.53 \mathrm{~b}$ \\
\hline Total porosity $(\%)$ & $88.58 \mathrm{a}$ & $83.18 \mathrm{~b}$ & $62.54 \mathrm{c}$ \\
\hline Water retention $(\%)$ & $69.92 \mathrm{a}$ & $66.84 \mathrm{a}$ & $49.68 \mathrm{~b}$ \\
\hline Volumetric density $\left(\mathrm{kg} \mathrm{m}^{-3}\right)$ & $280.0 \mathrm{c}$ & $450.0 \mathrm{~b}$ & $940.0 \mathrm{a}$ \\
\hline
\end{tabular}

Means followed by the same letter in the column do not differ by the Tukey test $(\mathrm{p} \leq 0.05)$.

The commercial substrate was suitable for the production of seedlings, with a $\mathrm{pH}$ of 6.36 (Table 1). However, it should be noted that although the $\mathrm{pH}$ value in the organic substrate $(8.35)$ was high. Ideal $\mathrm{pH}\left(\right.$ in $\left.\mathrm{H}_{2} \mathrm{O}\right)$ values for seedlings production are in range of 5.0-5.8 for substrates with predominance of organic matter and values between 6.0 and 6.5 for substrates with predominance of mineral soil (Kämpf; Fermino, 2000). However, the effect of pH to zinnia cultivate was no clearly evidenced, but it seems like this species grow up in a substrate with high $\mathrm{pH}$. In previous studies zinnia plants had great development and production in a mix of substrates compost de leaf manure mix (silt + leaf manure + coconut compost; 1:1:1) or in silt alone with $\mathrm{pH}$ above 7.5 and 7.8 , respectively (Riaz et al., 2008).

The electrical conductivity (EC) is an indicative of the concentration of salts in the solution and provides a parameter of the estimation of the amount of nutrients present in the substrates. EC values between 1.0 to $2.0 \mathrm{dS} \mathrm{m}^{-1}$ are normal and less than $1.0 \mathrm{dS} \mathrm{m}^{-1}$ are considered low (Araújo Neto et al., 2009). All substrates evaluated showed low salinity concentrations (Table 1), however, the commercial substrate recorded the highest EC value $\left(0.74 \mathrm{dS} \mathrm{m}^{-1}\right)$. Talebi et al. (2015) evaluating the influence of different $\mathrm{NaCl}$ concentrations on the morphophysiology of Zinnia elegans, found that the species has resistance to salinity, tolerating electrical conductivity up to $6 \mathrm{dS} \mathrm{m}-1$, above this value, the authors emphasize that there may be reduction in growth and plant development.

Concerning the substrates physical properties, it is important to note that a suitable relationship between macro and micropores is essential for the proper development of the seedlings in trays (Lopes et al., 2005). Thus, to obtain satisfactory results in the production of seedlings, adequate macroporosity values are sought between $35-45 \%$, microporosity between $45 \%-55 \%$ and total porosity between 75\%-85\%. (Maeda et al., 2007). The three substrates evaluated in this work presented adequate values for macro- 
porosity, being the commercial substrate with the highest percentage of macropores (Table 1). As for microporosity and total porosity, only the mix substrate (mixture of sand, soil and carbonized rice husk) was below the ideal range, due to the granulometry of the materials used. Low porosity materials can cause root gas exchange, water movement and drainage problems, negatively affecting root and plant development, as opposed to higher porosity mixtures, which can be beneficial for aeration and promotion of root development (Costa et al., 2017).

Carrijo et al. (2002) recommend values of total porosity above $85 \%$. According to Kämpf (2005), the total porosity is of fundamental importance for plant growth, since the high concentration of roots formed in containers requires a high oxygen supply and rapid removal of the carbon dioxide generated. The commercial substrate meets the recommendations of the aforementioned authors; however, the organic substrate presents values close to the ideal. However, the mix substrate was below ideal (Table 1).

The water retention capacity of a substrate plays a key role in providing water to the plants, the adequate levels of water retention capacity values is between $40 \%-60 \%$ (Fermino, 2014). Thus, the mix substrate conforms to the levels established by these authors (Table 1). The commercial and organic compost substrates recorded values close to the range considered adequate $(69.92 \%$ and $66.84 \%)$.

The volumetric density of a substrate is important to aid in the interpretation of other characteristics, such as porosity, aeration space and water availability (Barbosa and Lopes, 2007). In addition, knowing the volumetric density of a substrate is very important for the management, besides influencing the transport costs, handling and infrastructure necessary for its use (Fernandes et al., 2006).

It is considered as reference for substrates used in trays, values of volumetric density between 100 and 300 $\mathrm{kg} \mathrm{m}^{-3}$ (Kämpf, 2005). In this way, only the commercial substrate meets this reference for use in trays. The organic substrate showed avolumetric density above the proposed reference, possibly due to the types of residues used in the composting process, which influenced the obtaining a denser compound. In the mix substrate volumetric density was three times higher than the commercial substrate density, due to soil and sand fraction, whose mineral materials are much denser than organic matter. High density materials such as sand and soil, when used alone or in large proportions in the formulation of a substrate, become inconvenient due to their excessive weight, which makes it difficult to handle plants in the containers, reducing root penetrability and growth (Costa et al., 2017).

Schafer et al. (2015) highlight that the use of mineral components is still observed in many cases, which usually leads to substrates with very poor cultivation characteristics, corroborating the results obtained in this work for the substrate mix. Moreover, the authors point out that the use of soil in large proportions in nurseries leads to unsustainability, since its extraction causes environmental degradation in different proportions.

The highest growth of zinnia seedling was observed in height of 128-cell tray containing organic substratate; however, when used 200-cell there no significant difference was observed between commercial or organic compound (Figure 1A). Root length was higher when plants were grown on a 128-cell tray using commercial or organic substrate, but there was no significant difference between the roots length in plants obtained in any substrate in a 200-cell tray (Figure 1B).

The organic substrate allowed the production of the largest number of leaves in zinnia plants, when 128-cell trays (Figure 1C). However, this substrate did not differ from the commercial substrate when the plants were grown in 200-cell trays. The seedlings produced in a mix of substrates had the lowest number of leaves independent of the tray volume used for cultivation.

The dry weight of seedlings was significantly affected by the substrates, regardless of the cell volume of the trays (Figure 1D). However, when comparing cell volumes, it was observed that tray 128 allowed the accumulation of dry mass for commercial and organic substrates significantly larger than those produced in 200-cell trays. 
A

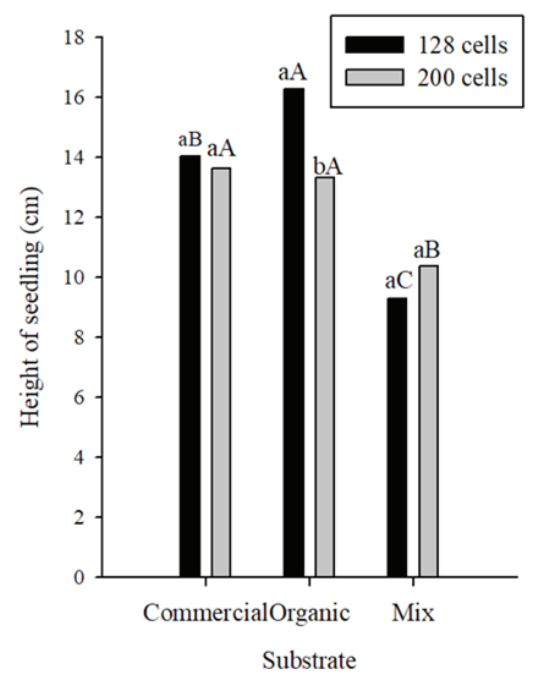

C

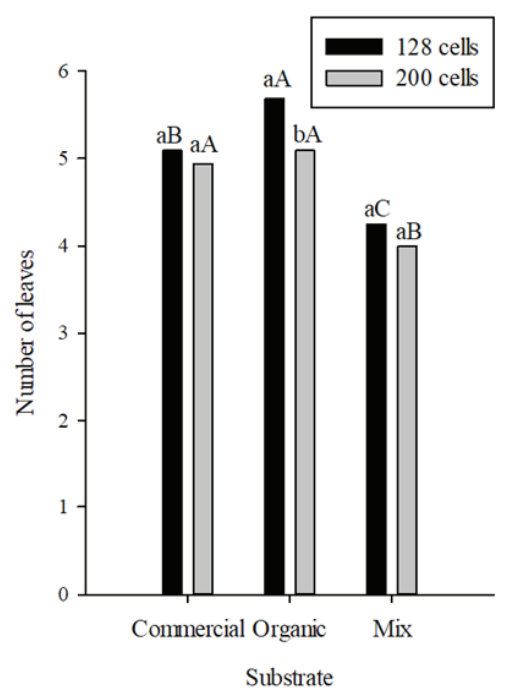

B

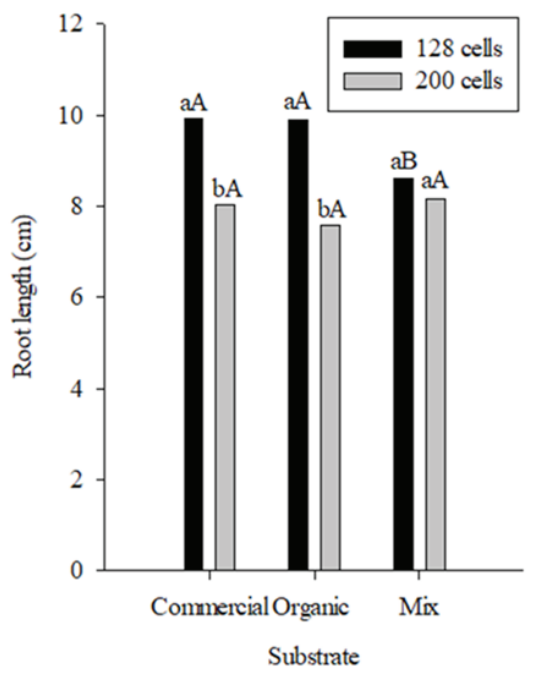

D

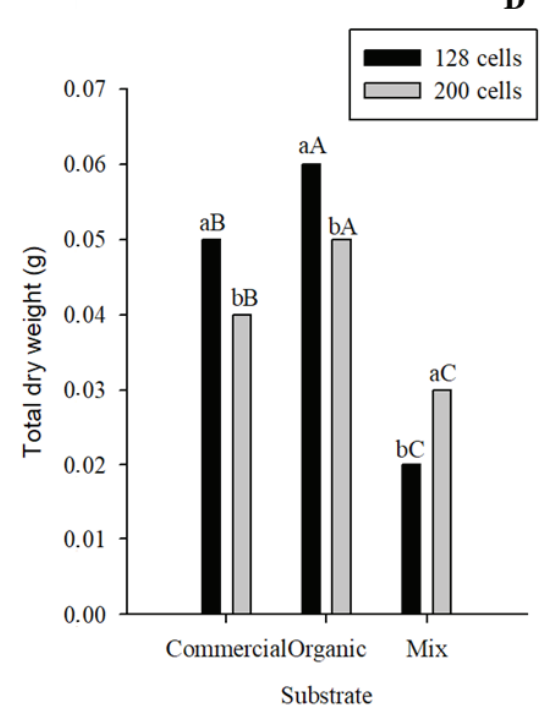

Figure 1. Height of seedling (A) and root length (B) Number of leaves (C) and total dry mass (D) of zinnia seedlings produced in trays of 128 and 200 cells containing the different substrates. Means values followed by different capital letters between the substrates under same size of cells, and lowercase letters between the size of cells under same substrate, significantly differ according to Tukey test $5 \%$.

According to the assignment of notes to vigor of the plants, it can be observed that the plants produced in organic substrate in trays of 128 cells allowed to obtain of plants with greater vigor, which presented leaves were more vigorous that those obtained on the same substrate in 200-cell trays (Figure 2A). However, when using the 200cell tray, the organic substrate does not significantly differ from the commercial substrate. The substrate mix allowed the production of seedlings less vigor in seedlings in both trays with plants showing a higher frequency of yellow and undeveloped leaves.

There was no significant difference in the vigor of the seedlings when the commercial substrate was used, regardless of the volume of the trays, indicating that the choice of the substrate is closely related to the type of trays to be used. In this case, it is necessary to evaluate the economic factors for seedling production. The vigor of seedlings comprises the physical and physiological properties that allow the adequate development of seedlings under field conditions. Thus, seedlings with high physiological quality provide the potential for the formation of a homogeneous stand and favors the initial growth of the seedlings, reflecting in the larger productivity (Pêgo et al., 2011).

The greatest stability of clod was obtained plants grown in organic substrate in a tray of 128 cells (Figure 2B). No significant difference was observed for the clod stability for the plants that were grown in 200 trays containing the organic and commercial substrates. The adhesion of the substrate to the root system of ornamental plants, at the moment of removal of the clod of the alveoli of the tray, avoids the dehydration and the damage of the roots, besides preserving their arrangement in the porous spaces of the substrate (Steffen et al., 2010). 

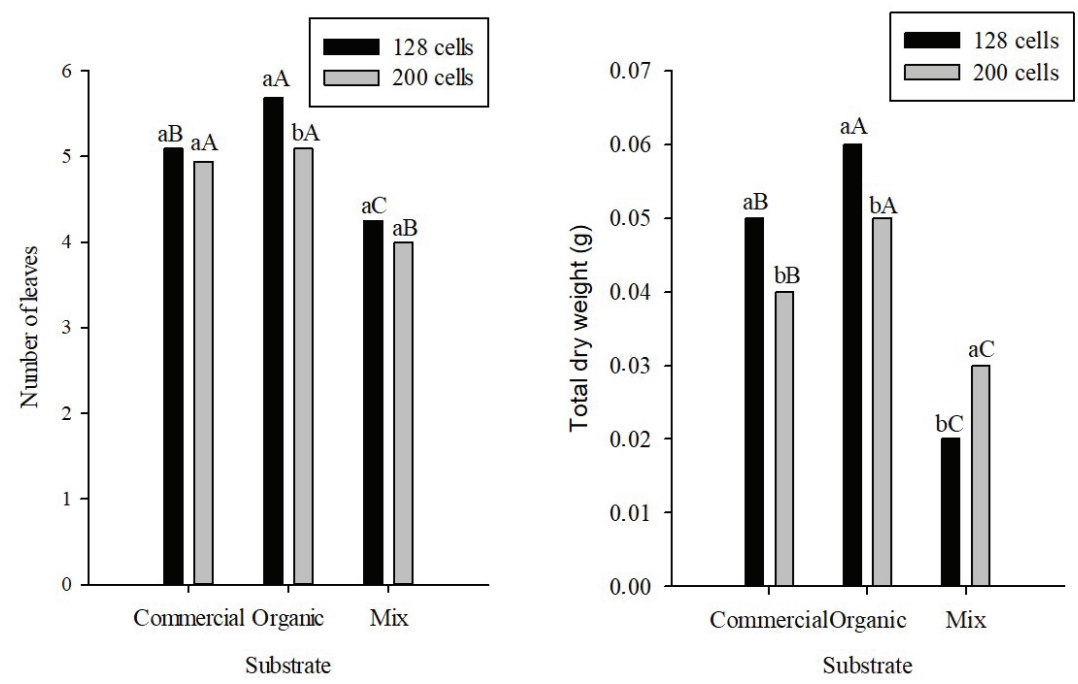

Figure 2. Vigor of seedling (A) and clod stability of substrates (B) of zinnia seedlings produced in trays of 128 and 200 cells containing the different substrates. Means values followed by different capital letters between the substrates under same size of cells, and lowercase letters between the size of cells under same substrate, significantly differ according to Tukey test $5 \%$.

There was significant effect on the stability of clods of the different cell trays. However, the substrate mix produced clod less cohesive and at evaluation time, it was observed that part of the clod had not been aggregated by the roots, possibly by the more sandy physical composition.

In general, the development of the plants of zinnia was benefited by the greater volume of substrate used in cell tray. The higher cell volume container provided better growth of the root and seedlings with more vigor because of its greater availability of nutrients and more space for the growth of the root (Costa et al., 2013). The production of seedlings in cell trays has been shown to be efficient in several aspects, such as substrate economy, greenhouse space, production of seedlings with high quality and high survival after field planting (Oliveira et al., 1993). However, this economy may be detrimental to the final production, because in smaller cells the amount of substrate may be insufficient for the proper development, reducing quality of the final product of the seedlings (Echer et al., 2007).

This results leads to a broader discussion. It is clear that the 128-cell tray produces high quality seedlings when organic substrate as substrate is used; however, it is important considerate that it is necessary to use 4.4 liters of substrate to fill a 128-cell tray and only 3.0 liters to fill a 200-cell tray, one a reduction of $32 \%$. Considering that the seedlings produced in smaller cell trays had relatively good vigor seedling and clod stability, the organic substrate obtained by composting from agricultural wastes can be an alternative for organic farmers in an agricultural production system. Furthermore, the 200-cell tray can enable the production of more seedlings per area.

As a rule, since the substrate does not affect the quality of the seedlings, the selection of the substrate should be made according to the availability of materials around the production to reduce costs and ensure the sustainability of production; thus, alternative substrates tend to be a good choice for ornamental horticulture (Barbosa and Lopes, 2007). These results are promising because in the case of a multipurpose ornamental species, the possibility of obtaining seedlings in organic substrates reinforces the idea of producing organic seedlings that will enable the production of zinnia as cut flower, potted plants or attractive plant in agroecological farming systems.

\section{Conclusion}

The physicochemical and physical proprieties of organic substrate enables to produce quality plants using 128 -cell trays, but the 200-cell trays also produce good seedlings quality, having the advantage of using smaller volumes of substrates.

\section{Author contribution}

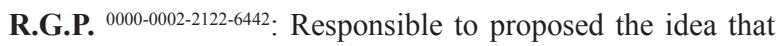
originated the work and elaborate hypotheses; structured the methodology, coordinated and wrote the manuscript. L.F.S.A. 0000-0001-8315-4213: Reviewed the literature, presented important suggestions incorporated into the work; statistical analysis. A.R.C.S. 0000-0001-8335-6480: Collected data and performed the routine work; wrote the manuscript.

\section{Acknowledgements}

The authors thank the Technical College of the Federal Rural University of Rio de Janeiro for making the greenhouse available for this experiment. 


\section{References}

AHMAD, I.; WHIPKER, B.E.; DOLE, J.M. Paclobutrazol or ancymidol effects on postharvest performance of potted ornamental plants and plugs. Hortscience, v.50, n.9, p.1370-1374, 2015. DOI: https://doi.org/10.21273 / HORTSCI.50.9.1370

ALI, Y.S.S. Effect of Mixing date palm leaves compost (DPLC) with vermiculite, perlite, sand and clay on vegetative growth of dahlia (Dahlia pinnata), marigold (Tagetes erecta), zinnia (Zinnia elegans) and cosmos (Cosmos bipinnatus) plants. Research Journal of Environmental Sciences, v.5, n.7, p.655-665, 2011. DOI:https://scialert.net/abstract/?doi=rjes.2011.655.665

ANTUNES, L.F.S.; SCORIZA, R.N.; FRANCA, E. M.; SILVA, D. G.; CORREIA, M. E. F.; LEAL, M.A.A.; ROUWS, J.R.C. Desempenho agronômico da alface crespa a partir de mudas produzidas com gongocomposto. Brasilian Journal of Sustainable Agriculture, v.8, n.3, p.56-55, 2018b. DOI: https://doi.org/10.21206/rbas.v8i3.3009

ARAÚJO NETO, S.E.; AZEVEDO, J.M.A.; GALVÃO, R.O.; OLIVEIRA, E.B.L.; FERREIRA, R.L.F. Produção de muda orgânica de pimentão com diferentes substratos. Ciência Rural, v.39, n.5, 2009. DOI:. http://dx.doi. org/10.1590/S0103-84782009005000099

BARBOSA, J.G.; LOPES, L.C.; GROSSI, J.A.S.; MAPELI, A.M. Propagação vegetativa artificial. In: BARBOSA, J.G.; LOPES, L.C. (ed.). Propagação de plantas ornamentais. Viçosa: UFV, 2007. p.109-144.

BHERING, L.L. Rbio: A tool for biometric and statistical analysis using the $\mathrm{R}$ platform. Crop Breeding and Applied Biotechnology, v.17, 187-190p. 2017. DOI: http:// dx.doi.org/10.1590/1984-70332017v17n2s29

BRASIL. Ministério da Agricultura, Pecuária e Abastecimento. Instrução Normativa $n^{\circ} 46$. de 6 de outubro de 2011. Estabelece o regulamento técnico para os sistemas orgânicos de produção animal e vegetal. Diário Oficial da União.. 2011.

BRASIL. Ministério da Agricultura, Pecuária e Abastecimento. Instrução Normativa SDA N. ${ }^{\circ} 31$. Diário Oficial da União-Seção 1. 24 de outubro de 2008. Alteração dos subitens 3.1.2. 4.1 e 4.1.2 da Instrução Normativa n. ${ }^{\circ} 17$ de 21/05/2007. Métodos Analíticos Oficiais para Análise de Substratos para Plantas e Condicionadores de Solo, Brasília. 2008

CARRIJO, O.A.; LIZ, R.S.; MAKISHIMA, N. Fibra de casca de coco verde como substrato agrícola. Horticultura Brasileira, v.20, p.533-535, 2002. DOI: http://dx.doi. org/10.1590/S0102-05362002000400003
COSTA, J.C.F.; MENDONÇA, R.M.N.; FERNANDES, L.F.; OLIVEIRA, F.P.; SANTOS, D. Caracterização física de substratos orgânicos para o enraizamento de estacas de goiabeira. Revista Brasileira de Agropecuária Sustentável, v.7, n.2, p.90-96, 2017. DOI: http://dx.doi. org/10.21206/rbas.v7i2.390.

COSTA, E; DURANTE, L.G.Y; SANTOS, A; FERREIRA $\mathrm{C}, \mathrm{R}$. Production of eggplant from seedlings produced in different environments, containers and substrates. Horticultura Brasileira, v.31, n.1, p.139-146, 2013. DOI: http://dx.doi.org/10.1590/S0102-05362013000100022.

ECHER, M.M.; GUIMARÃES, V.F.; ARANDA, A.N.; BORTOLAZZO, E.D.; BRAGA, J.S. Avaliação de mudas de beterraba em função do substrato e do tipo de bandeja. Semina: Ciências Agrárias, v.28, n.1, p.45-50, 2007. DOI: http://dx.doi.org/10.5433/1679-0359.2007v28n1p45.

FERMINO, M.H. Substratos: composição, caracterização e métodos de análise. Guaíba: Agrolivros, 2014. 112p.

FERNANDES, C.; CORÁ, J.E.; BRAZ, L.T. Desempenho de substratos no cultivo do tomateiro do grupo cereja. Horticultura Brasileira, v.24, p.42-46, 2006. DOI: http:// dx.doi.org/10.1590/S0102-05362006000100009.

FRANZIN, S.M.; MENEZES, N.L.; GARCIA, D.C.; SANTOS, O.S. Efeito da qualidade das sementes sobre a formação de mudas de alface. Horticultura Brasileira, v.23, n.2, p.193-197, 2005. http://dx.doi.org/10.1590/ S0102-05362005000200006.

GODOY, M.C.; CARDOSO, A.I.I. Produtividade da couve-flor em função da idade de transplantio das mudas produzidas e tamanhos de células na bandeja. Horticultura Brasileira, v.23, n.3, p.837-840, 2005. http://dx.doi. org/10.1590/S0102-05362005000300029

GOMAA, A.A.; SAMY, M.N.; DESOUKEY, S.Y.; KAMEL, M.S. A comprehensive review of phytoconstituents and biological activities of genus Zinnia. Journal of Advanced Biomedical and Pharmaceutical Sciences, v.2, n.1, p.29-37, 2019. DOI: 10.21608/jabps.2018.5599.1024.

IQBAL, D.; HABIB, U., ABBASI, N.A.; CHAUDHRY, A.N. Improvement in postharvest attributes of zinnia (Zinnia elegans cv. Benary's giant) cut-flowers by the application of various growth regulators. Pakistan Journal of Botany, v.44, n.3, p.1091-1094, 2012.

KÄMPF, A.N. Substrato. In: KAMPF, A.N. Produção comercial de plantas ornamentais, 2ed. Guaíba: Agrolivros, 2005. p.45-72.

KÄMPF, A.N.; FERMINO, M.H. Substratos para plantas: a base da produção vegetal em recipientes. Porto Alegre: Genesis, 2000. 312p. 
LEAL, M.A.A; GUERRA, J.G.M; PEIXOTO, R.T.G; ALMEIDA, D.L. Utilização de compostos orgânicos como substratos na produção de mudas de hortaliças. Horticultura Brasileira, v.25, n.3, p.392-395, 2007. DOI: http:// dx.doi.org/10.1590/S0102-05362007000300014.

LOPES, J.L.W.; GUERRINI. I.A.; SAAD, J.C.C.; SILVA, M.R. Efeitos da irrigação na sobrevivência, transpiração e no teor relativo de água na folha em mudas de Eucalyptus grandis em diferentes substratos. Scientia Forestalis, v.68, p.97-106, 2005.

MAEDA, S.; DEDECEK, R.A.; AGOSTINI, R.B.; ANDRADE, G.C.; SILVA, H.D. Caracterização de substratos para produção de mudas de espécies florestais elaborados a partir de resíduos orgânicos. Pesquisa Florestal Brasileira, n.54, p.97-104, 2007.

MIYAJIMA, D. Causes of low double-flowered seed production in breeding zinnia. Journal of the American Society for Horticultural Science, v.120, n.5, p.759-764, 1995. DOI: https://doi.org/10.21273/JASHS.120.5.759

MORAES, E.R.M.; SANTANA, A.S.; PEIXOTO, J.F.M.; SILVA, R.. Use of alternative waste wood substrates in the production of seedlings zinnia. African Journal of Agricultural Research, v.11, n.33, p.3090-3096, 2016. DOI: https://doi.org/10.5897/AJAR2016.11305

OLIVEIRA, R.P.; SCIVITTARO, W.B.; VASCONCELLOS, L.A.B.C. Avaliação de mudas de maracujazeiro em função do substrato e do tipo de bandeja. Scientia Agrícola, v.50, n.2, p.261-266, 1993. DOI: http://dx.doi. org/10.1590/S0103-90161993000200014.

PÊGO, R.G.; NUNES, U.R.; MASSAD, M.D. Qualidade fisiológica de sementes e desempenho de plantas de rúcula no campo. Ciência Rural, v.41, n.8, p.1341-1346, 2011. http://dx.doi.org/10.1590/S0103-84782011000800008.

PINTO, A.C.R.; RODRIGUES, T.J.D.; LEITE, I.C.L.; BARBOSA, J.C. Efeitos de tamanho de vaso e sistemas de condução no desenvolvimento e qualidade de cultivares de zinia. Revista Brasileira de Horticultura Ornamental, v.9, n.1, p.53-62, 2003.

RIAZ, R.; ARSHAD, M.; YOUNIS, A.; RAZA, A.; HAMEED, M. Effects of different growing media on growth and flowering of Zinnia elegans cv. Blue point. Pakistan Journal of Botany, v.40, n.4, p.1579-1585, 2008.
SANTOS JÚNIOR, J.A.; GHEYI, A.R.; PÉREZ-MARIN, A.M.; DIAS, N.A.; GUEDES FILHO, D.H. Substrates and time intervals of renewal of wastewater in production and post-harvest of the ornamental sunflower. Revista Ciência Agronômica, v.45, n.3, p.469-478, 2014. http://dx.doi. org/10.1590/S1806-66902014000300006.

SARDOEI, A.S.; FAHRAJI, S.S.; GHASEMI, H. Effects of different growing media on growth and flowering of zinnia (Zinnia elegans). International journal of Advanced Biological and Biomedical Research, v.2, n.6, p.18941899, 2014. DOI: https//:10.3923/rjes.2015.302.306

SCHAFER, G.; SOUZA, P.V.D.; FIOR, C.S. Um panorama das propriedades físicas e químicas de substratos utilizados em horticultura no sul do Brasil. Ornamental Horticulture, v.21, n.3, p.299-306, 2015. DOI: https://doi. org/10.14295/oh.v21i3.735

SILVA, D.G.; ANTUNES, L.F.S.; SCORIZA, R.N.; CARVALHO, J.F.; CORREIA, M.E.F. Crescimento de mudas de hortaliças em substratos orgânicos. Cadernos Agroecológicos, v.13, p.1-6, 2018.

SOUSA, H.H.F.; BEZERRA, F.C.; ASSIS JÚNIOR, R.N.; FERREIRA, F.V.M.; SILVA, T.C.; CRISÓSTOMO, L.A. Produção de mudas de Zinnia elegans em substratos à base de resíduos agroindustriais e agropecuários em diferentes tamanhos de recipientes. Revista Brasileira de Horticultura Ornamental, v.17, n.2, p.115-120, 2011. DOI: https://doi.org/10.14295/rbho.v17i2.706

STEFFEN, G.P.K.; ANTONIOLLI, Z.I.; STEFFEN, R.B.; BELLÉ, R. Húmus de esterco bovino e casca de arroz carbonizada como substratos para a produção de mudas de boca-de-leão. Acta Zoológica Mexicana, v.2, n.Especial, p.345-357, 2010. DOI: https://doi.org/10.21829/ azm.2010.262899

TALEBI, S.F.; MORTAZAVI, S.N.; SHARAFI, A. Effect of salinity on some morphophysiological traits of Zinnia elegans. Environmental Stresses in Crop Sciences, 2015. DOI: 10.22077 / ESCS.2015.187.

TEIXEIRA, P.C.; DONAGEMA, G.K.; FONTANA, A.; TEIXEIRA, W.G. Manual de métodos de análise do solo, 3ed. Brasília: Embrapa, 2017, 573 p.

WIJESINGHE, S.A.E.C., KARUNARATHNE, W.A.I.P. AND YAKANDAWALA, K. Designing with wild plants for maximizing insect richness in urban areas. Acta Horticulture. n.1189, p. 497-500, 2017. DOI: https://doi. org/10.17660/ActaHortic.2017.1189.99 